\section{Factors associated with body mass index changes among older adults: a ten-year follow-up}

\author{
Fatores associados a alterações no índice de \\ massa corporal entre idosos: um seguimento \\ de dez anos
}

\section{Factores asociados con índice de masa corporal entre adultos mayores: un seguimiento de 10 años}

Tânia Aparecida de Araujo 1,2

Ligiana Pires Corona ${ }^{3}$

Flavia Cristina Drumond Andrade 4

Manuela de Almeida Roediger 1

Yeda Aparecida de Oliveira Duarte 1

\begin{abstract}
To examine changes in body mass index (BMI) among older Brazilian adults and associated factors. Longitudinal, population-based study, conducted in São Paulo, Brazil. Adults aged 60 years or over $(n=1,796)$ from the first wave of data collection from the Health, Well-Being, and Aging Study (SABE Project) conducted from 2000 to 2010. Repeated mixed-effects linear regression was used to analyze longitudinal changes in BMI and to examine whether sociodemographic characteristics, health conditions, and social behaviors were associated with these changes. Mean BMI decreased after 70 years. Men had lower BMI than women ( $\beta=-1.86,95 \% \mathrm{CI}:-2.35$; -1.37$)$. Older adults who consumed alcohol ( $\beta=0.30,95 \% \mathrm{CI}: 0.06 ; 0.54)$, had more than one chronic disease $(\beta=0.19,95 \% \mathrm{CI}: 0.26 ; 0.72)$ and who did not perform physical activity ( $\beta=0.56$, 95\%CI: 0.38; 0.74) had higher BMI. Subjects who smoked $(\beta=-0.40,95 \% C I:-0.76 ;-0.04)$ and who reported having eaten less food in recent months $(\beta=-0.48,95 \% C I$ : $-0.71 ;-0.24)$ had lower BMI. In older Brazilians, several sociodemographic characteristics, health conditions, and behaviors predict BMI. Increasing prevalence of chronic diseases and growing sedentary behaviors in Brazil may have detrimental effects on BMI at older ages.
\end{abstract}

Aged; Aging; Body Mass Index

\author{
Correspondence \\ T. A. Araujo \\ Rua Tapuios 1305, Uberlândia, MG 38408-416, Brasil. \\ tanniaraujo@hotmail.com.br \\ 1 Faculdade de Saúde Pública, Universidade de São Paulo, São \\ Paulo, Brasil. \\ 2 Centro Universitário de Patos de Minas, Pato de Minas, Brasil. \\ 3 Universidade Estadual de Campinas, Campinas, Brasil. \\ ${ }_{4}$ University of Illinois at Urbana-Champaign, Urbana, U.S.A.
}




\section{Introduction}

Due to the burden of chronic diseases associated with increased body mass index (BMI) and obesity in the population 1, measures to reduce weight, such as reducing the intake of unhealthy foods and encouraging physical exercise 2 , have been supported worldwide. However, for older adults, the relationship of BMI (and its changes) to health status is more complex ${ }^{3}$. Generally, body weight tends to decline gradually at older ages. Weight loss in old age is mainly a result of reduced ability to preserve homeostatic mechanisms that control hunger and satiety 4 . Besides, several physiological changes occurring in old age contribute to changes in body composition among older adults 5 , such as reduced height due to vertebral compression and changes in intervertebral discs, increase in total body fat percentage, decrease in muscle mass, fat redistribution, central fat, bone changes due to lower calcification levels and decrease of body water content 5 .

According to data from the Protective and Risk Factors for Chronic Diseases by Telephone Survey (Vigitel), a system that provides annual estimates on the prevalence of overweight and obesity in the adult population of all Brazilian capitals, the prevalence of obesity increased from $11.6 \%$ to $17.4 \%$ from 2006 to 2012, representing an average increase of $0.9 \%$ per year. This increase was lower among individuals aged 65 and older (0.7\% a year), but still significant 6 . Between the 1970s and 2013, the median BMI increased in all segments of the Brazilian population, mainly among older adults, women, and people with lower schooling levels 7,8 .

Understanding which variables are associated with body composition - such as BMI - can help predict health outcomes, such as cardiovascular disease risks and frailty 9,10. BMI is also widely used in clinical practice and research and has a high correlation with weight 11 . While much is understood about factors associated with BMI at older ages in developed countries, less is known about these associations in middle-income countries 12 . Moreover, most studies are based on cross-sectional data 7,8,13,14,15, with few exceptions 16,17. Given the rapid nutritional transitions ongoing in these countries, obtaining information about older adults' health is critical 18, mainly due to the consequences for disability and mortality 19 . We address this gap in the literature by examining the factors associated with body weight, based on BMI, among Brazilian older adults using longitudinal data.

\section{Methods}

\section{Participants}

This study comprises a sample of participants from the Health, Well-Being, and Aging Study (SABE Project), a cohort study that began in 2000. The participants were selected using a multiple-stage probabilistic sample that is representative of community-dwelling individuals aged 60 years or older dwelling in the city of São Paulo, Brazil 20. In 2006, a second wave of the study was conducted, in which 1,115 of the participants from the first wave were re-interviewed. A third wave was conducted in 2010/2011 with 748 people who had participated in both the first and second waves of the study. In this study, we included only participants with complete data on weight and height, at least in the baseline. Figure 1 shows the details of the sample used in all waves.

Trained interviewers collected data in household interviews using a structured questionnaire that addressed socioeconomic variables, general health, living conditions, and anthropometric measures - details on the methodology in Andrade et al. 20.

\section{Measures}

The dependent variable was BMI $\left(\mathrm{kg} / \mathrm{m}^{2}\right)$, calculated by dividing body weight (in kilograms) by the square of height (in meters). A trained interviewer measured body weight using a calibrated scale and height using a stadiometer fixed to a wall, all individuals were barefoot, wearing light clothing.

Sociodemographic characteristics were obtained as follows: sex, age (in years), race (white, mixed black, other races - Asian, indigenous), schooling level (illiterate, 1-3 years, $\geq 4$ years) and marital 
Figure 1

Sample of older adults in each data collection. Health, Well-Being, and Aging Study (SABE Project), Brazil, from 2000 to 2010.

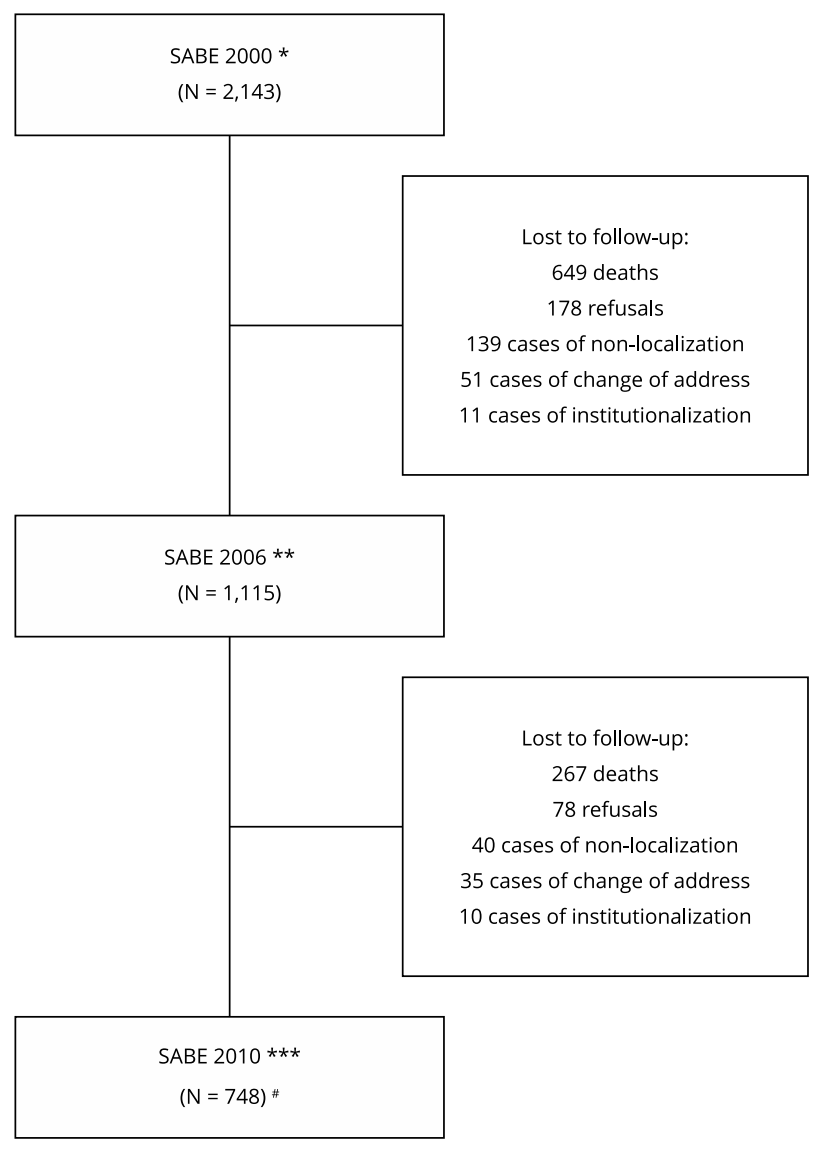

* 347 incomplete anthropometric data in 2000;

** 79 incomplete anthropometric data in 2006;

*** 90 incomplete anthropometric data in 2010;

\# 63 individuals who participated only in 2000 and 2010.

status (married, not married - divorced, separated or widowed/widower). Age and marital status were the only sociodemographic characteristics included as time-varying.

Self-reported health conditions were as follows: self-rated health (good, not good); number of chronic diseases diagnosed by physician (categorized as up to one disease and two or more diseases): hypertension, diabetes, cancer, chronic pulmonary disease, stroke, cardiovascular disease, and osteoarthritis. All health conditions were included as time-varying.

Behavioral aspects were as follows: physical activity (yes, no), whether the participant reported eating less (yes, no), alcohol consumption (yes, no), and current smoking (yes, no). The level of weekly physical activity was assessed using the Brazilian version of the International Physical Activity Questionnaire. Individuals who reported practicing physical activity less than three times a week were classified as physically inactive. Those who answered positively to the question "In the past three months, have you decrease your food intake?" were categorized as eating less. Alcohol intake was assessed by asking participants whether they were non-drinkers, drank once a week, drank two to six days a week, or drank every day. Given the low prevalence of any alcohol consumption, the participants 
were divide into non-drinkers and drinkers (those who drank any alcohol). All behavioral variables were included as time-varying.

Furthermore, to examine potential confounding effects of death commonly seen in longitudinal studies, a mortality indicator variable was included to indicate whether the participant died during the study period.

\section{Statistical analyses}

Descriptive statistics (means, standard deviations, and percentages) were used to provide estimates at baseline. The Lowess curve ${ }^{21}$ was used to evaluate the BMI trends across age. The same methodology was used to examine whether BMI changes differed across sociodemographic, health, and behavioral characteristics over time. Results (not shown) indicate differences in BMI at baseline and linear trends in BMI across age. Marital and multimorbidity status also showed differences in BMI changes.

A repeated mixed-effects linear regression was used to analyze longitudinal changes in BMI and to examine which factors were associated with BMI changes over time 22 . Repeated mixed-effects regressions handle nested data inherent to repeated observations within individuals and allow the comparison of an unequal number of observations across individuals. BMI was treated as a continuous variable.

We examined whether BMI as a function of age followed a linear growth - and we included random effects - that allows individuals to vary in the initial level BMI. Also, random slopes were included to evaluate the variability in BMI growth rate. Unconditional model (not shown) included only age as a covariate indicated that the model followed a linear growth with random intercept and random slope. Then, covariates were included, and finally, interactions with age were tested. The final model includes all covariates and statistically significant interactions. Model diagnosis showed that the assumption of normally distributed residuals was met. Also, predicted values were close to the observed ones. Homoscedasticity of the errors seems to be met.

Thus, regression coefficients, confidence intervals, and p-values of this final model are presented. However, to facilitate the interpretation of regression results for the interaction effects, the linear predictions obtained with the "margins" command and the "marginsplot" command are used to graph the BMI levels across age. All data analyses were conducted using the statistical software Stata (https:// www.stata.com).

\section{Ethics considerations}

The datasets analyzed in the current study were used under license and are not publicly available due to the policies of the SABE Project. The SABE Project and this study were approved by the Research Ethics Committee of the Faculty of Public Health at the University of São Paulo, control numbers 315 (2000), 83 (2006) and 2,044 (2010), and by the Brazilian National Research Ethics Committee. All participants signed an informed consent form to participate in the study.

\section{Results}

Table 1 shows the characteristics of the participants at baseline. The mean BMI was $26.3 \mathrm{~kg} / \mathrm{m}^{2}$ and the mean age was 72.9 years. Most of the sample was female (59.4\%).

Table 2 shows the association of BMI, sociodemographic characteristics, self-reported health conditions, behavioral aspects, and mortality. Model 1 includes all the covariates, whereas model 2 adds the two statistically significant interaction terms to model 1.

Results from model 2 show that men had lower BMI than women ( $\beta=-1.93,95 \% \mathrm{CI}:-2.41 ;-1.46)$. Older adults who consumed alcohol $(\beta=0.33,95 \%$ CI: $0.09 ; 0.57)$, and who did not perform physical activity ( $\beta=0.51,95 \%$ CI: $0.33 ; 0.69)$ had higher BMI. Subjects who smoked $(\beta=-0.49,95 \% \mathrm{CI}$ : -0.86 ; -0.13 ) and who reported having eaten less food in recent months ( $\beta=-0.48,95 \%$ CI: $-0.74 ;-0.23)$ had lower levels of BMI. Figure 2 shows the BMI trends for marital status and multimorbidity. Results indicate that after age 70 years, married older adults have higher BMI levels than unmarried. Older 
Table 1

Characteristics at baseline. Health, Well-Being, and Aging Study (SABE Project), Brazil, 2000.

\begin{tabular}{|c|c|}
\hline Characteristics & Baseline \\
\hline BMI $\left(\mathrm{kg} / \mathrm{m}^{2}\right)$ [mean (SD)] & $26.34(4.89)$ \\
\hline Age (years) [mean (SD)] & $72.93(8.25)$ \\
\hline \multicolumn{2}{|l|}{ Sex $[\%]$} \\
\hline Female & $1,067(59.41)$ \\
\hline Male & 729 (40.59) \\
\hline \multicolumn{2}{|l|}{ Race [\%] } \\
\hline White & $1,258(70.40)$ \\
\hline Mixed or black & $439(24.57)$ \\
\hline Other races & $90(5.04)$ \\
\hline \multicolumn{2}{|l|}{ Schooling level (years) [\%] } \\
\hline Illiterate & $421(23.55)$ \\
\hline $1-3$ & $490(27.40)$ \\
\hline$\geq 4$ & $877(49.05)$ \\
\hline \multicolumn{2}{|l|}{ Marital status [\%] } \\
\hline Married & $952(53.04)$ \\
\hline Not married & $843(46.96)$ \\
\hline \multicolumn{2}{|l|}{ Health condition [\%] } \\
\hline Good & $815(45.48)$ \\
\hline Not good & $977(54.52)$ \\
\hline \multicolumn{2}{|c|}{ Number of chronic diseases [\%] } \\
\hline No or 1 & $995(57.55)$ \\
\hline$\geq 2$ & $734(42.45)$ \\
\hline \multicolumn{2}{|l|}{ Physical activity [\%] } \\
\hline Yes & $424(23.61)$ \\
\hline No & $1,372(76.39)$ \\
\hline \multicolumn{2}{|l|}{ Eating less [\%] } \\
\hline No & $1,411(78.61)$ \\
\hline Yes & $384(21.39)$ \\
\hline \multicolumn{2}{|l|}{ Alcohol [\%] } \\
\hline No & $1,266(70.49)$ \\
\hline Yes & $530(29.51)$ \\
\hline \multicolumn{2}{|l|}{ Smoking [\%] } \\
\hline No & $982(54.71)$ \\
\hline Yes & $813(45.29)$ \\
\hline
\end{tabular}

SD: standard deviation.

adults with multimorbidity have higher BMI levels than those with no multimorbidity, but the difference reduces at older ages.

\section{Discussion}

A stable BMI is an indicator of good health in old age, and it is a sign that the body can maintain homeostasis 23 . By contrast, changes suggest systemic deterioration, including both the decrease and the increase in BMI 24. In the SABE Project data, BMI tended to decrease with age, but not equally across groups. The decrease rate was faster for those who had two or more chronic conditions and those who were unmarried. 
Table 2

The association between body mass index (BMI) and sociodemographic characteristics, self-reported health conditions, behavioral aspects and mortality.

\begin{tabular}{|c|c|c|c|c|}
\hline & \multicolumn{2}{|c|}{ Model 1} & \multicolumn{2}{|c|}{ Model 2} \\
\hline & Coefficient & $95 \% \mathrm{Cl}$ & Coefficient & $95 \% \mathrm{Cl}$ \\
\hline \multicolumn{5}{|l|}{ Fixed effects } \\
\hline \multicolumn{5}{|l|}{ Sociodemographic } \\
\hline Age & -0.06 * & $-0.08 ;-0.04$ & -0.02 & $-0.04 ; 0.01$ \\
\hline \multicolumn{5}{|l|}{ Sex } \\
\hline Female & 1.00 & & 1.00 & \\
\hline Male & -1.94 * & $-2.41 ;-1.46$ & -1.93 * & $-2.41 ;-1.46$ \\
\hline \multicolumn{5}{|l|}{ Race } \\
\hline White & 1.00 & & 1.00 & \\
\hline Mixed or black & 0.02 & $-0.25 ; 0.29$ & -0.01 & $-0.28 ; 0.26$ \\
\hline Other races & -0.21 & $-0.62 ; 0.21$ & -0.24 & $-0.66 ; 0.18$ \\
\hline \multicolumn{5}{|l|}{ Education (years) } \\
\hline Illiterate & 1.00 & & 1.00 & \\
\hline $1-3$ & -0.02 & $-0.51 ; 0.46$ & -0.01 & $-0.49 ; 0.47$ \\
\hline$\geq 4$ & -0.22 & $-0.73 ; 0.29$ & -0.21 & $-0.72 ; 0.30$ \\
\hline \multicolumn{5}{|l|}{ Marital status } \\
\hline Married & 1.00 & & 1.00 & \\
\hline Not married & -0.24 & $-0.55 ; 0.07$ & $2.98 * *$ & $0.76 ; 5.20$ \\
\hline \multicolumn{5}{|l|}{ Health conditions } \\
\hline \multicolumn{5}{|l|}{ Self-rated health } \\
\hline Good & 1.00 & & 1.00 & \\
\hline Not good & 0.01 & $-0.19 ; 0.20$ & 0.00 & $-0.19 ; 0.20$ \\
\hline \multicolumn{5}{|l|}{ Multimorbidity } \\
\hline No or 1 & 1.00 & & 1.00 & \\
\hline$\geq 2$ & 0.51 * & $0.25 ; 0.76$ & 3.94 * & $2.07 ; 5.82$ \\
\hline \multicolumn{5}{|l|}{ Behavioral } \\
\hline \multicolumn{5}{|l|}{ Physical activity } \\
\hline Yes & 1.00 & & 1.00 & \\
\hline No & 0.48 * & $0.30 ; 0.67$ & 0.51 * & $0.33 ; 0.69$ \\
\hline \multicolumn{5}{|l|}{ Less food } \\
\hline No & 1.00 & & 1.00 & \\
\hline Yes & -0.49 * & $-0.75 ;-0.23$ & -0.48 * & $-0.74 ;-0.23$ \\
\hline \multicolumn{5}{|l|}{ Alcohol } \\
\hline No & 1.00 & & 1.00 & \\
\hline Yes & $0.33 * *$ & $0.08 ; 0.57$ & $0.33 * *$ & $0.09 ; 0.57$ \\
\hline \multicolumn{5}{|l|}{ Smoking } \\
\hline No & 1.00 & & 1.00 & \\
\hline Yes & $-0.50 * *$ & $-0.87 ;-0.13$ & $-0.49 * *$ & $-0.86 ;-0.13$ \\
\hline \multicolumn{5}{|l|}{ Mortality } \\
\hline No & 1.00 & & 1.00 & \\
\hline Yes & $-1.22 *$ & $-1.68 ;-0.76$ & $-1.22 *$ & $-1.68 ;-0.76$ \\
\hline \multicolumn{5}{|l|}{ Interactions } \\
\hline Marital status and age & & & $-0.043 * *$ & $-0.07 ;-0.01$ \\
\hline Multimorbidity and age & & & -0.046 * & $-0.07 ;-0.02$ \\
\hline Constant & 32.15 * & $30.66 ; 33.63$ & 28.85 * & $26.94 ; 30.76$ \\
\hline \multicolumn{5}{|l|}{ Random effects } \\
\hline Intercept & 11.36 & $9.28 ; 13.90$ & 10.84 & $8.74 ; 13.44$ \\
\hline Age & 0.14 & $0.12 ; 0.18$ & 0.14 & $0.11 ; 0.17$ \\
\hline Residual & 1.46 & $1.34 ; 1.59$ & 1.45 & $1.34 ; 1.58$ \\
\hline
\end{tabular}

95\% Cl: 95\% confidence interval.

$* p<0.001$;

$\star * p<0.01$. 


\section{Figure 2}

Predicted body mass index (BMI) values and $95 \%$ confidence interval $(95 \% \mathrm{Cl})$ by multimorbidity status and by marital status and age.

2a) Multimorbidity status

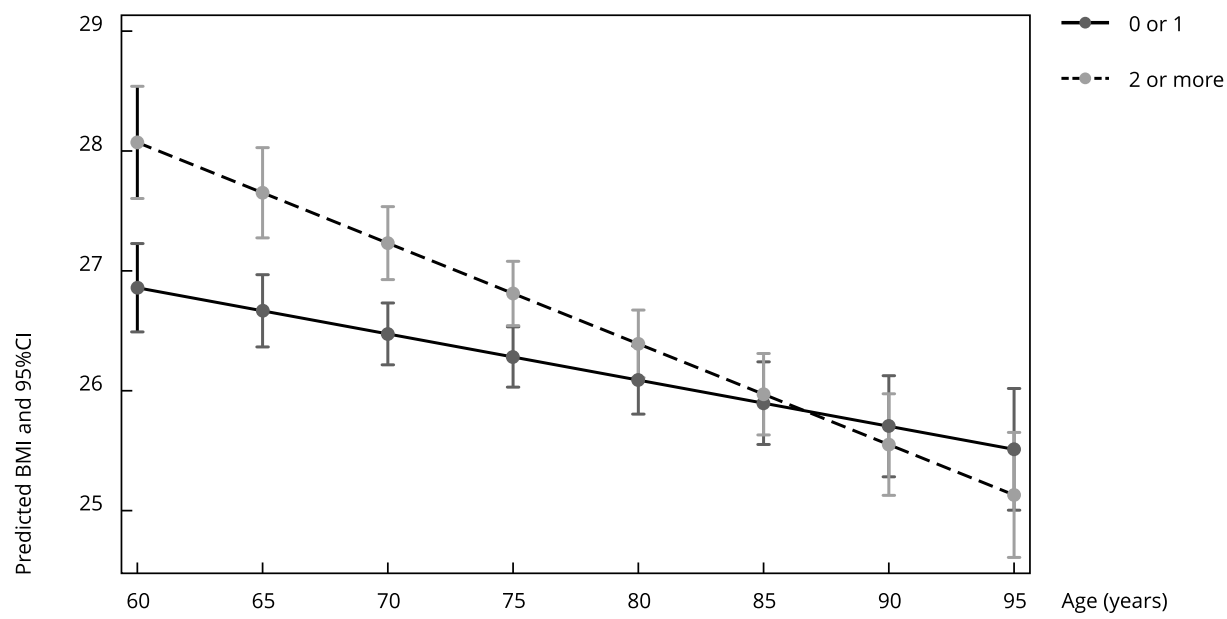

2b) Marital status

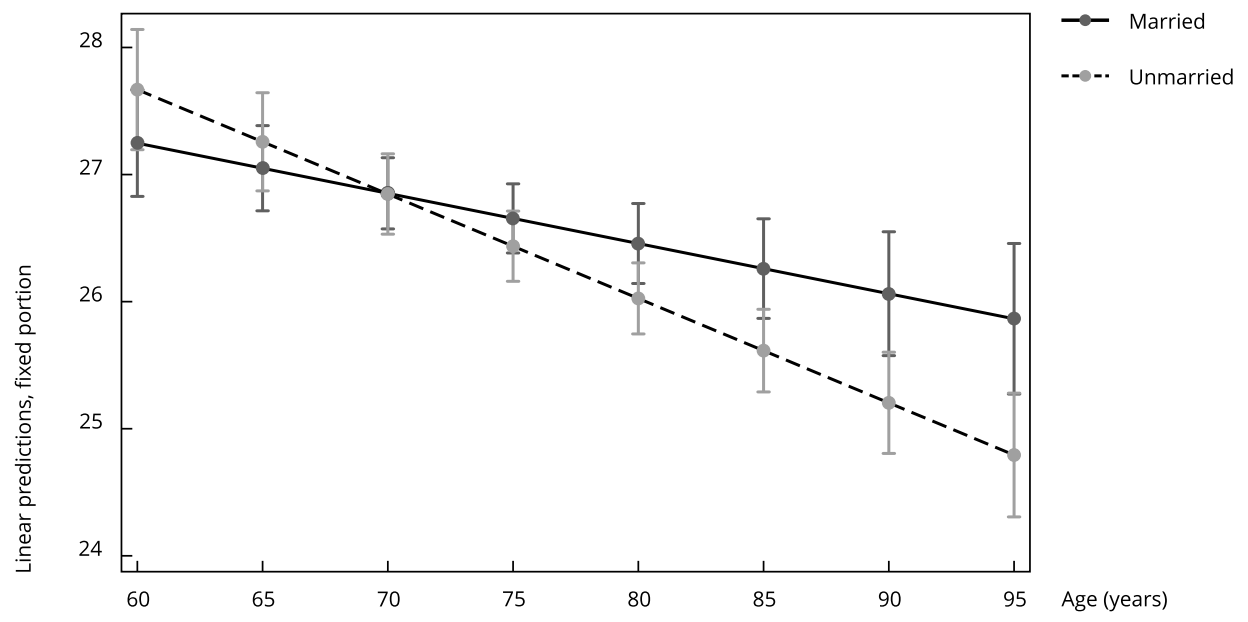

Increased BMI is a known risk factor for developing chronic diseases such as diabetes and hypertension 11,25. This could explain the general tendency towards higher BMI among those with multimorbidity. Data from this work has shown that from the age of 85 years onwards, individuals with two or more chronic diseases tend to have a lower BMI - for those with none or one disease. Diseases such as cancer and lung diseases, due to catabolic or inflammatory stress 26 , can increase the energetic expenditure, leading to lower body weight and BMI. This process may become more evident at advanced ages or with disease progression.

In this work, participants aged over 70 years old had a lower BMI when they were not married. Some who are married may have better assistance on daily tasks, such as shopping and cooking, affecting healthy weight maintenance. In the United States, older adults who lived alone without 
family or friends nearby had the lowest consumption of fruits and vegetables 27 . In Japan, individuals who had difficulty to shop, which is more common among older individuals and people with culinary inabilities, showed worse food choices 28 .

Although the relative risks of a high BMI become less pronounced as a person ages 12, the progressive increase in BMI and obesity among older adults, especially among women, has alarmed experts 3 . The effects of menopause 29 , and behavioral factors such as an improved ability to prepare food 30 , may be related to the higher BMI among women. This study results are similar to those of Asp et al. 31, who reported lower body weight among older men.

Current studies indicate that obesogenic environments that stimulate deleterious habits have also contributed to increased BMI even among older individuals 32 . We showed that physical inactivity and alcohol consumption were related to higher BMI. According to Gomes 33, major physical factors in weight gain in old age are modifiable, such as inactive lifestyles. Evidence generated from experimental studies also indicates that regular participation in physical activities promotes the preservation of skeletal muscle mass, strength, and physical function with advancing age 34 .

In contrast to the results found in this study, other studies 35 have shown that older people who consume alcohol have lower BMI than those who do not. Because alcohol affects inhibition of brain regions, such as the hypothalamus, large amounts of alcohol may reduce food intake 36 , while limited amounts of alcohol may increase appetite 37 . Also, because alcohol effects on blood can be longlasting in older people, even small amounts of alcohol can exacerbate chronic diseases occurrence and development 38 .

Reports of decreased food intake and smoking, on the other hand, were associated with lower levels of BMI. In addition to conditions directly related to food consumption, such as reduced odor and taste, delayed gastric emptying, pathological conditions (cancer, lung diseases, dementia), and psychosocial factors (loneliness and mourning) also contribute to weight loss in old age 39. A proinflammatory effect and reductions in taste and food intake 40 may also be related to weight loss among smokers.

Debate continues about the best weight, or ideal weight, in old age. For example, it is postulated that the weight that maximizes survival would increase with age ${ }^{3}$. However, it is also possible that people who are susceptible to the adverse effects of obesity die early as weight does not increase survival, such as those who survive to old age may be resistant to the detrimental effects of obesity 3 . Our results demonstrated a negative association between mortality and BMI. Other studies also found that not only weight loss 41 but also overall weight changes - weight gain and weight fluctuations - were associated with higher mortality 12,42 .

Obesity and related health problems are becoming growing problems in low- and middle-income countries 43 , and addressing these problems in contexts of poverty, social inequalities, and inadequate access to health care 18 is a challenge. Still, there is little information on factors associated with BMI among older adults in these countries. Our study addresses this gap. Another strength of our study is the use of measured weight and height rather than self-reported measures. The limitations of this study include the fact that height was considered constant during the study period. Also, the classification of respondents with chronic diseases relied upon self-report, although the wording of the question specified physician diagnosis.

Obese older adults are a rising demographic and an important focus for further research. The convergence of aging and increases in BMI will carry significant financial and societal burdens, especially in developing countries. Public agencies and governments must be prepared for this new reality. 


\section{Contributors}

T. A. Araujo and F. C. D. Andrade made substantial contributions to the conception and design of the study and performed the statistical analyses. L. P. Corona participated in the statistical analyses, the design of the study and critically reviewing the manuscript for significant intellectual content. M. A. Roediger critically reviewed significant intellectual content. Y. A. O. Duarte provided final approval for the version to be published, conceived the study, and participated in its wrigting and coordination.

\section{Additional informations}

ORCID: Tânia Aparecida de Araujo (0000-00015894-8695); Ligiana Pires Corona (0000-00015298-7714); Flavia Cristina Drumond Andrade (0000-0002-3856-3816); Manuela de Almeida Roediger (0000-0001-6680-128X); Yeda Aparecida de Oliveira Duarte (0000-0003-3933-2179).

\section{Conflicts of interest}

The authors declare no conflict of interest.

\section{Acknowledgments}

To the main investigator and coordinator of the SABE Project, Maria Lucia Lebrão, in memoriam. This work was supported by the São Paulo State Research Foundation (FAPESP, grant number 99/05125-7) and Brazilian Graduate Studies Coordinating Board (CAPES, grant number 1570936).

\section{References}

1. Afshin A, Forouzanfar MH, Reitsma MB, Sur P, Estep K, Lee A, et al. Health effects of overweight and obesity in 195 countries over 25 years. N Engl J Med 2017; 377:13-27.

2. Ding D, Lawson KD, Kolbe-Alexander TL, Finkelstein EA, Katzmarzyk PT, van Mechelen $\mathrm{W}$, et al. The economic burden of physical inactivity: a global analysis of major non-communicable diseases. Lancet 2016; 388:1311-24.

3. Cetin DC, Nasr G. Obesity in the elderly: more complicated than you think. Cleve Clin J Med 2014; 81:51-61.

4. Roberts SB, Rosenberg I. Nutrition and aging: changes in the regulation of energy metabolism with aging. Physiol Rev 2006; 86:651-67.

5. JafariNasabian P, Inglis JE, Reilly W, Kelly OJ, Ilich JZ. Aging human body: changes in bone, muscle and body fat with consequent changes in nutrient intake. J Endocrinol 2017; 234:R37-51.

6. Malta DC, Andrade SC, Claro RM, Bernal RTI, Monteiro CA. Trends in prevalence of overweight and obesity in adults in 26 Brazilian state capitals and the Federal District from 2006 to 2012. Rev Bras Epidemiol 2014; 17:267-76

7. Wagner KJP, Boing AF, Cembranel F, Boing ACS, Subramanian SV. Change in the distribution of body mass index in Brazil: analysing the interindividual inequality between 1974 and 2013. J Epidemiol Community Health 2019; 73:544.

8. Gomes DCK, Sichieri R, Verly Junior E, Boccolini CS, de Moura Souza A, Cunha DB. Trends in obesity prevalence among Brazilian adults from 2002 to 2013 by educational level. BMC Public Health 2019; 19:965.

9. Khan SS, Ning H, Wilkins JT, Allen N, Carnethon M, Berry JD, et al. Association of body mass index with lifetime risk of cardiovascular disease and compression of morbidity. JAMA Cardiol 2018; 3:280-7.

10. Ferriolli E, Pessanha FPAS, Moreira VG, Dias RC, Neri AL, Lourenço RA. Body composition and frailty profiles in Brazilian older people: Frailty in Brazilian Older People Study-FIBRABR. Arch Gerontol Geriatr 2017; 71:99-104.

11. Diverse Populations Collaborative Group. Weight-height relationships and body mass index: some observations from the Diverse Populations Collaboration. Am J Phys Anthropol 2005; 128:220-9.

12. Cheng FW, Gao X, Jensen GL. Weight change and all-cause mortality in older adults: a meta-analysis. J Nutr Gerontol Geriatr 2015; 34:343-68.

13. Andrade FCD, López-Ortega M. Educational differences in health among middle-aged and older adults in Brazil and Mexico. J Aging Health 2017; 29:923-50.

14. Wagner KJP, Bastos JL, Navarro A, Boing AF. Socio-economic life course and obesity among adults in Florianopolis, southern Brazil. Gac Sanit 2018; 32:244-50. 
15. Diniz MFHS, Beleigoli AMR, Ribeiro ALP, Vidigal PG, Bensenor IM, Lotufo PA, et al. Factors associated with metabolically healthy status in obesity, overweight, and normal weight at baseline of ELSA-Brasil. Medicine (Baltimore) 2016; 95:e4010.

16. Souza LG, Jardim TV, Rezende AC, Sousa ALL, Moreira HG, Perillo NB, et al. Predictors of overweight/obesity in a Brazilian cohort after 13 years of follow-up. Nutr J 2018; 17:10.

17. Callo G, Gigante DP, Barros FC, Horta BL. Excesso de peso/obesidade no ciclo da vida e composição corporal na idade adulta: coorte de nascimentos de Pelotas, Rio Grande do Sul, Brasil, 1982. Cad Saúde Pública 2016; 32:e00174014.

18. Chatterji S, Byles J, Cutler D, Seeman T, Verdes E. Health, functioning, and disability in older adults: present status and future implications. Lancet 2015; 385:563-75.

19. Schaap LA, Quirke T, Wijnhoven HAH, Visser $M$. Changes in body mass index and mid-upper arm circumference in relation to all-cause mortality in older adults. Clin Nutr 2018; $37(6$ Pt A):2252-9.

20. Andrade FCD, Guevara PE, Lebrão ML, Duarte YAO, Santos JL. Gender differences in life expectancy and disability-free life expectancy among older adults in São Paulo, Brazil. Womens Health Issues 2011; 21:64-70.

21. Royston P, Cox NJ. A multivariable scatterplot smoother. Stata J 2005; 5:405-12.

22. McCulloch C, Searle SR. Generalized, linear, and mixed models. New York: Wiley; 2000.

23. Magkos F. Metabolically healthy obesity: what's in a name? Am J Clin Nutr 2019; 110:533-9.

24. Park SY, Wilkens LR, Maskarinec G, Haiman CA, Kolonel LN, Marchand LL. Weight change in older adults and mortality: the Multiethnic Cohort Study. Int J Obes (Lond) 2018; 42:205-12.

25. Chooi YC, Ding C, Magkos F. The epidemiology of obesity. Metabolism 2019; 92:6-10.

26. Bruins MJ, Van Dael P, Eggersdorfer M. The role of nutrients in reducing the risk for noncommunicable diseases during aging. Nutrients 2019; 11:85.

27. Choi YJ, Ailshire JA, Crimmins EM. Living alone, social networks in neighborhoods, and daily fruit and vegetable consumption among middle-aged and older adults in the USA. Public Health Nutr 2020; 23:3315-23.

28. Ishikawa M, Yokoyama T, Nakaya T, Fukuda Y, Takemi Y, Kusama K, et al. Food accessibility and perceptions of shopping difficulty among elderly people living alone in Japan. J Nutr Health Aging 2016; 20:904-11.

29. Greendale GA, Sternfeld B, Huang M, Han W, Karvonen-Gutierrez C, Ruppert K, et al. Changes in body composition and weight during the menopause transition. JCI Insight 2019; 4:e124865.
30. Rugel EJ, Carpiano RM. Gender differences in the roles for social support in ensuring adequate fruit and vegetable consumption among older adult Canadians. Appetite 2015; 92:102-9.

31. Asp M, Simonsson B, Larm P, Molarius A. Physical mobility, physical activity, and obesity among elderly: findings from a large population-based Swedish survey. Public Health 2017; 147:84-91.

32. Roberto CA, Swinburn B, Hawkes C, Huang TT, Costa SA, Ashe M, et al. Patchy progress on obesity prevention: emerging examples, entrenched barriers, and new thinking. Lancet 2015; 385:2400-9.

33. Gomes M, Figueiredo D, Teixeira L, Poveda V, Paúl C, Santos-Silva A, et al. Physical inactivity among older adults across Europe based on the SHARE database. Age Ageing 2017; 46:71-7.

34. Zampieri S, Pietrangelo L, Loefler S, Fruhmann H, Vogelauer M, Burggraf S, et al. Lifelong physical exercise delays age-associated skeletal muscle decline. J Gerontol A Biol Sci Med Sci 2015; 70:163-73.

35. Ishikawa M, Yokoyama T, Murayama N. Alcohol energy intake is related to low body mass index in japanese older adults: data from the 2010-2011 national health and nutrition survey. J Nutr Health Aging 2017; 21:1095-101.

36. Lewis MJ. Alcohol and nutrient intake: mechanisms of reinforcement and dependence. Physiol Behav 2011; 104:138-42.

37. Bach P, Koopmann A, Kiefer F. The impact of appetite-regulating neuropeptide leptin on alcohol use, alcohol craving and addictive behavior: a systematic review of preclinical and clinical data. Alcohol Alcohol 2021; 56:149-65.

38. Barry KL, Blow FC. Drinking over the lifespan: focus on older adults. Alcohol Res 2016; 38:115-20.

39. Kiesswetter E, Colombo MG, Meisinger C, Peters A, Thorand B, Holle R, et al. Malnutrition and related risk factors in older adults from different health-care settings: an enable study. Public Health Nutr 2020; 23:446-56.

40. Stojakovic A, Espinosa EP, Farhad OT, Lutfy $\mathrm{K}$. Effects of nicotine on homeostatic and hedonic components of food intake. J Endocrinol 2017; 235:R13-31.

41. Haugsgjerd TR, Dierkes J, Vollset SE, Vinknes KJ, Nygård OK, Seifert R, et al. Association between weight change and mortality in community living older people followed for up to 14 years. The Hordaland Health Study (HUSK). J Nutr Health Aging 2017; 21:909-17.

42. Beleigoli AM, Diniz MDFH, Boersma E, Silva JL, Lima-Costa MF, Ribeiro AL. The effects of weight and waist change on the risk of longterm mortality in older adults: the Bambuí (Brazil) Cohort Study of Aging. J Nutr Health Aging 2017; 21:861-6.

43. Popkin BM, Adair LS, Ng SW. Global nutrition transition and the pandemic of obesity in developing countries. Nutr Rev 2012; 70:3-21. 


\section{Resumo}

O objetivo foi examinar alterações no indice de massa corporal (IMC) e fatores associados em idosos brasileiros. Este foi um estudo longitudinal, populacional, realizado em São Paulo, Brasil. Os participantes eram adultos com 60 anos ou mais $(n=1.796)$ da primeira onda da coleta de dados do Projeto Saúde, Bem-Estar e Envelhecimento (Projeto $S A B E$ ), realizada entre 2000 e 2010. Foi usada regressão linear de medidas repetidas de efeitos mistos para analisar as mudanças longitudinais no IMC e examinar a associação entre características sociodemográficas, condições de saúde e comportamentos sociais e essas mudanças. O IMC médio diminuiu depois dos 70 anos de idade. Os homens tinham IMC mais baixo que as mulheres ( $\beta=-1,86$, IC95\%: -2,35; - 1,37). Os idosos que consumiam álcool ( $\beta=0,30$, IC95\%: 0,06; $0,54)$, com mais de uma doença crônica $(\beta=0,19$, IC95\%: 0,26; 0,72) e que não praticavam atividade física ( $\beta=0,56$, IC95\%: 0,38; 0,74) tinham IMC mais alto. Idosos fumantes ( $\beta=-0,40$, IC95\%: $-0,76 ;-0,04)$ e que relatavam menor consumo alimentar nos últimos meses ( $\beta=-0,48$, IC95\%: -0,71; -0,24) tinham IMC mais baixo. Entre os idosos brasileiros, diversas características sociodemográficas, condições de saúde e comportamentos predizem o IMC. O aumento da prevalência de doenças crônicas e de comportamentos sedentários no Brasil pode ter efeitos prejudiciais sobre o IMC nas idades mais avançadas.

Idoso; Envelhecimento; Índice de Massa Corporal

\section{Resumen}

El objetivo fue examinar cambios en el indice de masa corporal (IMC) entre adultos mayores brasileños y sus factores asociados. Estudio longitudinal de base poblacional, llevado a cabo en São Paulo, Brasil. Los participantes eran adultos con 60 años o más $(n=1.796)$ de la primera ronda de recogida de datos procedentes de la Encuesta sobre Salud, Bienestar y Envejecimiento (Proyecto $S A B E$ ), realizado entre 2000 y 2010. Se usó una regresión lineal mixta de efectos repetidos para analizar cambios longitudinales en el IMC, y examinar si las características sociodemográficas, condiciones de salud y comportamientos sociales estuvieron asociados con estos cambios. La media del índice de masa corporal decreció después de los 70 años. Los hombres tenian un indice de masa corporal más bajo que las mujeres ( $\beta=-1,86$, IC95\%: -2,35; - 1,37). Los adultos mayores que consumieron alcohol ( $\beta=0,30,95 \% C I: 0,06 ; 0,54)$, tenian más de una enfermedad crónica ( $\beta=0,19$, IC95\%: $0,26 ; 0,72)$ y quienes no realizaban ninguna actividad física ( $\beta=0,56$, IC 95\%: 0,38; 0,74) tenian un mayor índice de masa corporal. Los individuos que fumaban ( $\beta=-0.40$, IC95\%: -0,76; -0,04) y quienes informaron de haber comido menos en los últimos meses ( $\beta=-0,48$, IC95\%: -0,71; -0,24) tenian un indice de masa corporal más bajo. En los brasileños más viejos, diversas características sociodemográficas, condiciones de salud, y comportamientos predicen el indice de masa corporal. La prevalencia ascendente de enfermedades crónicas, así como los crecientes comportamientos sedentarios en Brasil pueden tener efectos perjudiciales en el indice de peso corporal en las edades más avanzadas.

Anciano; Envejecimiento; Índice de Masa Corporal
Submitted on 14/Apr/2020

Final version resubmitted on 14/Jan/2021

Approved on 02/Mar/2021 